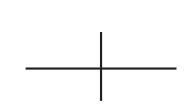

ARTICLE

\title{
Restorative justice as empowerment: how to better serve the goals of punitive retribution
}

\author{
Theo van Willigenburg ${ }^{*}$
}

\begin{abstract}
Restorative justice practices are applied only to the margins of criminal justice systems. These systems generally punish the wrongdoer in order to give him his "just desert'. For restorative justice to be more attractive, we need to understand why punitive retribution is such a powerful motive. If the scales of justice are out of balance because of suffering inflicted (to the offended), why would the infliction of more suffering (to the offender) bring redemption? It is argued that much of the sting of being harmed by an offender derives from the identity implications of the act. Punitive retribution may satisfy short-lasting vindictive desires, but its main symbolic function is to restore the victim's self-image and dignity by humiliating the perpetrator. This is done in a notoriously indirect and ineffective way, though. It is argued that restorative justice can do much better, if it is understood in terms of empowering the offended. This involves procedures that restore the victim's autonomy, prestige and self-confidence. Apart from bringing the offended back into the driver's seat of the process, restorative justice empowers the survivors of crime by helping them face offenders, face themselves and face their community. Restorative justice is not only much more rewarding than punitive retribution, it also provides better ways of communicating personal and public disapproval of crime.
\end{abstract}

Keywords: Restorative justice, retributive punishment, empowerment of victims, restoring dignity and autonomy in survivors of crime.

\section{The satisfaction from well-executed retribution}

This is the famous story from the Book of Esther in the Hebrew Bible (Esther 2:21-7:11): the wise Jew Mordecai, who once saved the king's life by revealing the plot of two assassins, has deeply insulted Haman, a high official just promoted to the most prominent position in the kingdom. While all the royal officials come to pay their respect and bow before the proud Haman, Mordecai refuses to play the game and does not kneel and pay Haman honour. Haman is furious and plans to kill not only Mordecai but all the Jewish kinsmen with him, women and children

* Theo van Willigenburg is resident research fellow at VU University Amsterdam and director of the Kant Academy, Utrecht (The Netherlands). 
included. He deceives the king into signing a law that will result in a genocide and already erects - in front of his house - a 75-foot-high gallows on which Mordecai will be hanged.

By accident - the sleepless king has the chronicles of his kingdom recited in his bedroom - the story of the prevented assassination is brought back to the king's mind and he learns that the wise Mordecai has never been rewarded for his intervention. Next morning, the king asks Haman, who entered the palace in order to obtain the king's permission to hang Mordecai, what honour should be given to a man who has served the kingdom so well as to protect the king's life. Haman, who mistakenly assumes that the king is referring to him, suggests a pompous ride on the king's horse through the city streets, robed in the king's garments and with a royal crest placed on the head. The king commands that Mordecai will be given that honour and Haman is forced to lead Mordecai on horseback through the city streets, proclaiming before him, 'This is what is done for the man the king delights to honour!'

Even more enraged by this event, Haman takes console in the invitation for a royal banquet by one of the king's concubines, Esther, not knowing that she is Mordecai's niece and thus Jewish.

At the banquet, Esther in tears reveals to the king that she and her people are about to be destroyed and pleads for the king to rescue her. When the king asks who is responsible, she points out Haman as the one who has planned the killing. Haman realises that the evil he was organising is now turned upon his own head. He begs Esther for his life, falling down on her couch (which even more enrages the king). Haman is being hung on the pole he had set up for Mordecai. Finally, the king rewards Mordecai by giving him Haman's position at the court.

The Book of Esther was included into the Hebrew canon in spite of the fact that the holy name of God is never mentioned in the text, making the book's status questionable. ${ }^{1}$ Even so, the story was immensely popular, probably because of the intricate way in which the evil character, Haman, is being repaid. People enjoy stories like these because there is something profoundly attractive and satisfying about well-executed retribution. Psychological research shows that retribution is especially satisfactory if it makes the perpetrator suffer in ways that psychologically fit the wrong done (Haidt, Sabini, Gromet \& Darley, 2010: 1-3). The proud Haman is forced to lead Mordecai on the king's horse through the streets and in the end is killed on the gallows that he had erected for Mordecai. For retribution to be successful, it is also important that the perpetrator knows that his suffering is meant as punishment for his wrongdoing. People do not regard harm that by accident comes to the evildoer (a murderer dies from sudden cerebral hemorrhage) as genuine retribution. The evildoer should know why he is suffering in order for retribution to be effective and satisfying. That is why well-executed ret-

1 Although the Council of Jamnia in 90 CE regarded the book as canonical, it was not regarded as such by the Essene community of Qumran (it is the only book from the Hebrew Bible not presented among the Dead Sea scrolls), and it is criticised in the Talmud. Even so, it is a featured text in Jewish liturgy, read during the important festival of Purim (or Hanukkah), the festival that it was ostensibly written to authorise. See Berlin (2001); Moore (1971). 
ribution should follow a precise plotline: 'The avenger typically devises a plan, whereby she will, in a process whose narrative is itself of value, end up giving whom she perceives to be a wrongdoer what the wrongdoer deserves' (Zaibert, 2006: 105). This explains the complexity (and popularity!) of the famous narratives of revenge like the Count of Monte Christo and Hamlet. The most valued expressions of high culture (Medea, Illiad, Odysseia) are especially enjoyed because of the tales about the way the wronged protagonist in the end settles the score. Retribution is the more satisfying if planned and if it unfolds slowly but surely.

But exactly because of such well-executed ways of 'getting them back', one could regard retribution as a profoundly immoral motive and practice. The urge for punitive retribution not only is a primitive instinct, it also reveals the dark side of the human soul: our capacity to design intricate plans for making someone suffer and our enjoyment in fantasising about such plans and executing them. No wonder that thinkers from old times have tried to distinguish (primitive, barbaric) retribution from civilised ways of punishing wrongdoers. As I will shortly argue, however, ideas of 'enlightened' punishment generally do not change the deep urge for punitive retribution. Retribution ('just desert') is for most people the primary motive for sentencing wrongdoers (Darley 2010; Mattinson \& Mirrlees-Black, 2000; Robinson, 2013). That is why so many thinkers have tried to justify what seems at first glance an absurdity in the practices of retribution, that is, the way it aims to restore evil (done to a victim) by doing evil to the perpetrator. Retribution of violence against victims by making the perpetrator suffer simply adds violence to violence. Why would adding suffering to suffering bring the scales of justice closer to balance? What does it solve?

I will argue that not the suffering of the perpetrator as such, but the (indirect) effect of retribution on the standing of the victim and the relationship with the perpetrator explains why the just deserts motive is so appealing to people. Much of the sting of being harmed by the perpetrator derives from the identity implications of the act. To be taken advantage of, exploited or hurt is resented because it implies that one is the sort of person who can be taken advantage of, exploited or hurt. Retribution is sought for because it may have a function in restoring the victim's self-image and dignity. I will use studies in (moral) philosophy, (social) psychology and victimology to investigate the background of this specific function of retribution and then argue for two theses:

1 The goals of retribution are not well served by the acts of retribution. Retribution is an ill-advised solution. There are better ways to accomplish what retribution aims to accomplish.

2 Restorative justice can provide such better ways if it is understood in terms of empowering victims. This involves procedures that strengthen victims' autonomy and dignity, promote clarification (through dialogue and face-toface encounters with offenders) and give victims voice as defenders of shared values. 
But first, I will sketch the classical moves in the direction of civilised punishment, before investigating what the powerful motive of retribution might bring victims (and observers).

\section{Distinguishing primitive revenge from 'enlightened' retribution}

Take Plato:

No one punishes a wrong-doer putting his mind on what they did and for the sake of this, unless one takes mindless vengeance like a wild beast. But he who undertakes to punish with reason does not avenge himself for the past offence \&; he looks rather to the future, and aims at preventing that particular person and others who see him punished from doing wrong again (Plato, Protagoras $324 \mathrm{a}-\mathrm{b})$.

This is one of the oldest attempts to distinguish the enlightened goals of punishment (the prevention of wrongdoing) from its more primitive drives (vengeance). In modern ethical theory, we distinguish so-called utilitarian, prospective goals, like specific/general deterrence and the incapacitation of the perpetrator, from deontological, retrospective goals: righting a wrong by administering a punishment proportionate to the harm done (just desert). ${ }^{2}$ Most people will endorse both types of goals to justify punishment (Gromet \& Darley, 2009; Orth, 2003). They say that they value deterrence equally to deservingness as motives for sentencing perpetrators (Weiner, Graham \& Reyna, 1997). Even so, there is a distinction between what people say and what they do when it comes up to assigning punishment. Research shows that when people are asked about their punishment preference in cases of a single individual who has committed a crime, their application of the deterrence justification is remarkably low (Carlsmith \& Darley, 2002). In their motivation for assigning punishment in cases of prototypical wrongdoing (a harm intentionally inflicted on another by a perpetrator), the deservingness-based stance dominates. People punish the wrongdoer in order to give him his just desert rather than to achieve any future goal. Sentences are not affected by considerations about preventing future offences through incapacitating the perpetrator or deterring potential villains (Darley, Carlsmith \& Robinson, 2000). It seems that in concrete cases just desert for most people is the primary sentencing motive, because punitive retribution provides a necessary expression of moral outrage (Frijda, 1994: 136; Hart, 1968: 255). Retribution communicates to the perpetrator severe disapproval of the moral wrong done and the need for

2 Going back to classical sources like Immanuel Kant who defended an enlightened version of the lex tallionis in his Metaphysik der Sitten (Kant, 1996: 473): 'Judicial punishment can never be used merely as a means to promote some other good for the criminal himself or for civil society \&, but must be pronounced over all criminals proportionate to their internal wickedness' and to Jeremy Bentham who argued that 'general prevention ought to be the chief end of punishment, as it is its real justification' (Bentham, 1962: 396). 
the perpetrator to be accountable for that wrongness (Duff, 2011; Duff, 2001b chaps. 4 and 6).

The prevailing dominance of the 'just desert' motive might partly explain why late modernity has not resulted in a larger number of 'enlightened' criminal policies with a growing focus on crime prevention and rehabilitation of trespassers. On the contrary, it has brought us an unprecedented phenomenon of mass incarceration, not only in non-democratic states like China, but also in a democracy like the United States, which currently has the largest proportion of its population imprisoned. ${ }^{3}$ It might explain why in countries like the Netherlands the length of average prison sentence has doubled since the period of 'leniency' in the 1960s and 1970s, and why the number of 'lifers' in Holland has increased 300 per cent since the seventies (Van Wely, 2013). It might explain why people endorse harsher sentencing or the death penalty even if this has no use in terms of deterring potential criminals or preventing recidivism (Durlauf \& Nagin, 2011; Radelet \& Lacock, 2009). And finally, it might explain why ideas of restorative justice and reconciliatory practices operate only in the fringe of most criminal justice systems (Fattah, 2007), despite the growing public attention for the position of victims, the need for restoration of their dignity and for the repair of harms done (but see De Mesmaecker, 2010). ${ }^{4}$

Because retribution is such a powerful motive, numerous attempts have been made to justify it by distinguishing it as a civilised motive from (primitive) revenge. According to a well-known argument by Robert Nozick (1983: 366-368), revenge is emotional, personal, unlimited and unruled, while retribution sets an internal limit to the amount of the punishment, does not involve the bloodthirsty emotional tone of revenge and is ruled by the general principles of justice. It is not difficult to show, however, that the distinction between revenge and retribution is more rhetorical than analytic (Walker, 1995; Zaibert, 2006). Research shows that for most people satisfactory revenge does not involve more violence than the original (often they even want it to be less violent), need not be emotional (but rather well-executed) and is bound to all kind of norms (Elster 1990; Haidt et al., 2010: 21). Retribution is nothing more than well-dressed revenge. Both have the same psychological function and play the same sociocultural role, despite the oddity of doing justice by adding violence to violence. It is no surprise that philosophers and psychologists have for long tried to justify exactly this accumulation of violence as something that is psychologically necessary and morally acceptable.

3 See the ranking of prison population in 223 countries on the website of the Centre for Prison Studies in London at www.prisonstudies.org/highest-to-lowest (last accessed 12 May 2018). See also Simon (2000).

4 Even Howard Zehr, a principled defender of the restorative approach to justice, has to acknowledge that, given the dominance of the retributive framework, it might be more realistic to seek 'areas of collaboration' and 'move as far as we can toward a process that is restorative' (Zehr, 2014: 58-59). 


\section{What might retribution bring victims (and observers)?}

The question is: why would punitive retribution restore the balance of justice? If the scales are out of balance because of suffering inflicted, why would the infliction of more suffering bring redemption? The straightforward answer is that the balance of suffering is restored because the suffering caused by the perpetrator is compensated by the enjoyment of seeing that the perpetrator gets his due (as Alfred Hitchcock said: 'Revenge is sweet and not fattening'). ${ }^{5}$ The expectation of revenge indeed seems to be pleasurable to people. Brain research shows that the (anticipation of) punishment of a defector or villain is associated with the neural signs of pleasure (De Quervain et al., 2004). Brain scans with functional magnetic resonance imaging (fMRI) show that there is an increased activation in rewardrelated brain areas when defectors are punished, together with strongly reduced empathy-related responses when people observe the defector receiving pain (Singer et al., 2006). No wonder that people predict that taking revenge against a person who wronged them will make them feel better about the incident.

Even so, psychological research shows that despite participants' expectation, those who acted on their desire for retribution reported more negative feelings than those who did not have the opportunity to take revenge (Carlsmith, Wilson \& Gilbert, 2008). For advocates of the 'just desert' reaction, this is a disturbing result. Experiments make clear that the positive expectations of people surrounding revenge are not necessarily realised in its actual pursuit. A possible explanation of these findings may be the fact that in these experiments no 'audience' was included: a third party, peers or (vicarious) bystanders in front of which the perpetrator gets his due and is humiliated. There are numerous indications that retribution can only be powerful in bringing something if it is seen in function of restoring the status, prestige and autonomy of the victim by 'publicly' taking revenge on the perpetrator (Haidt et al., 2010: 3). Take the game-experiments that economists have conducted under the name 'ultimatum game'. In this game, one player (the proposer) receives a sum of money and proposes how to divide the sum between the proposer and the other player. The other player (the responder) chooses to either accept or reject this proposal. If the second player accepts, the money is split according to the proposal. If the second player rejects, neither player receives any money. It appears that responders typically reject most offers below 40 per cent of the total sum, leaving both players emptyhanded. Of course this is not rational in terms of realised outcomes: better have some part of the money than nothing. Even so, responders reject an uneven distribution, and proposers anticipate this by offering between 40 and 50 per cent of the money. Apparently, people regard the symbolic meaning of a poor offer as more important than the money they could get for free. Why would the proposer,

5 A more sophisticated answer, in line with Hegel's Philosophy of Right (Hegel, 1821/1967), does not focus on correcting the imbalance in the distribution of suffering, but rather on the restoration of the balance of equal rights (the perpetrator has negated the victim's right to security and therefore loses his right to immunity from punishment). But also then it is not clear why restricting the liberty of offenders would restore the rights of the victims, unless rebalancing is defined as a situation in which all parties have to loose. See Baehler (2007: 291-292 and 295). 
who by chance received an amount of money, be entitled a (considerably) bigger share? Responders experience a poor offer as disrespectful and refuse, so that the proposer gets nothing, even if this leaves the responders empty-handed too. They punish the proposer at their own cost, because they feel humiliated, which means that not only the proposer's offer is valued because of its symbolic meaning, but also the way the responder retaliates a poor offer by refusing it. Retribution stands in function of restoring the dignity of the disadvantaged party. This symbolic function is confirmed by various studies. The perception of disrespect appears to be a better predictor of the likelihood of a victim pursuing a claim than more objective features such as the degree of material or physical harm (Miller, 2001: 544).

The physical discomfort experienced by a victim of theft/attack/assault has been shown to be subordinate to the symbolic elements that are incorporated into that attack (Greenwell \& Dengerink, 1973: 70). That is why unintentional acts of harm provoke less anger and less retaliation than do intentional acts of harm (Miller, 2001: 536). The degree of intentionality attributed to the perpetrator is inversely related to the intensity of the victims' reaction to that harm (Bies \& Tripp, 1996). The reaction of the victim is dependent on how she perceives the perpetrator's state of mind (Tedeschi \& Nessler, 1993). No wonder that people are much more inclined to forego grievance procedures if they feel that the agent of harm is treating them with respect (Merry \& Silbey, 1984).

In general, being victimised is hurtful because it touches upon the victim's identity. This is the reason why victims are not content with a mere compensation (if possible) that restores the status quo (stolen goods are returned, damages are paid for). The violation they have experienced has not only material, but also (and often predominantly) symbolic meaning. Victimisation means that the offender has violently appropriated status and power over the victim and the wider community (Okimoto \& Wenzel, 2008). Punishing an offender then may serve the victim in three ways:

1 it restores the victim as an active actor (autonomy): she is no longer (just) a passive sufferer;

2 it restores the victim's prestige (status) by degrading and disempowering the offender (Wenzel, Okimoto, Feather \& Platow, 2008);

3 it gives the victim voice as a defender of the values that she and the offender are supposed to share (Braithwaite, 1989).

If victimisation means a loss of dignity, then the urge for retribution and 'getting the perpetrator back' might best be understood as an attempt to regain agency and dignity. Personal prestige is in many ways associated with autonomy and being strong enough not to let others take advantage of oneself. Standing up against one's opponent/oppressor and actively defending one's case is a mark of independent agency and self-worth. That is why it is so well understood and admired when victims say that they want to look their attacker in the eyes, for instance in the courtroom where he is brought to trial. Being able to face the per- 
petrator is for victims often a precondition to face oneself and one's community (Vidmar, 2001).

In the story of Esther, honour and dignity are the main values at stake (Laniak, 1998). Haman seeks revenge because his pride was hurt by Mordecai who himself upholds his identity and honour as Jew by not bowing before 'earthly princes'. Esther deserves deep respect for the way in which she risks her life by uninvitedly seeking the king's presence and asking him and Haman for a banquet in which she dares to accuse the highest official of the court (Laniak, 1998: 107 ff). But most pointedly, the dignity of the Jews is established at the moment they are allowed by the king to defend themselves with force against the attackers who aim to pursue the king's decree which unfortunately cannot be made undone (it is a law of the Medes and Persians).

\section{Better ways of serving the goals of retribution}

What victims apparently seek and observers wish for is regaining what is lost because of the symbolic function of the perpetrator's offence: dignity and autonomy. Regaining dignity is a relationship issue. A crime is 'a profound expression of disrespect for the victim as a person' (Achilles \& Zehr, 2001: 88). This is what makes being victimised so hurtful. Victims, therefore, require the restoration of respect from the side of the perpetrator who is the one who has insulted them in the first place. But victims also seek to regain standing within their community from which they may feel estranged, because - as a victim - they are part of a story of thwarted moral expectations. Transgressions are experienced as violations of values that were presumed to be shared between victim and offender. The fact that a crime questions such values not only undermines victims' social identity, but also threatens their experience of the world as a meaningful and normatively safe place (Wenzel \& Okimoto, 2010: 403-404).

Retributive punishment is sought for as a way of restoring respect and dignity in the victim and rebuilding trust and meaning. That is why some have defended retributive punishment as a form of restoration: 'restoration through retribution' (Duff, 2001a: 83, 2001b, 2011). According to this view, the infliction of hardship and pain is not the ultimate goal of punishment. The 'essential purpose should be to achieve restoration' (Duff, 2001a: 83).

Even so, retributive punishment is a notoriously indirect and inefficient way of serving that purpose. Retribution restores respect in the victim by publicly recognising the wrong that he has suffered, and by condemning, degrading and disempowering the offender (Kleinig, 2011; Okimoto \& Wenzel, 2008; Wenzel, Okimoto, Feather \& Platow, 2008). And it has the indirect function of signalling and communicating the import of values and norms (Duff, 2001b; Okimoto \& Wenzel, 2009). One might question whether there are not better, that is more direct and efficient ways to restore the status-power relationship and to renew social consensus with the offender about the values violated. What would be a better way to reach the important symbolic results for the victim that retribution has to effect via punishing the perpetrator? 
Restorative justice is a powerful alternative to retributive justice. Restorative justice - which is a term referring to a set of theories and practices that are critical of the existing criminal justice system - is promising because it understands transgressions and crimes not primarily as a violation of rules, but as a violation against persons and human relations (Zehr, 2014: 64-69; Zehr, 1990/2015). It sees crime as a relationship issue, which seems to be a good starting point, if restoring dignity in the victim (a relationship issue!) is the main goal of reacting to a crime. Restorative practices do not promote justice by putting perpetrators to trial, but through constructive dialogue between victims, offenders and their communities, seeking to identify obligations, to meet needs and to promote healing and dignity. In short, restorative justice promotes practices that directly foster the restoration of interpersonal respect and worth (Braithwaite, 2002; Zehr, 1998).

In practice, however, restorative justice procedures are used only in a tiny minority of cases as an alternative to the usual criminal justice procedures. Psychologists suggest that people prefer restorative procedures only in cases of less severe crimes and in cases in which they share an identity and expect value consensus between victim and perpetrator (Gromet \& Darley, 2009; Okimoto, Wenzel, \& Feather, 2012). It appears, however, that these alleged preferences are highly dependent on the way restorative justice is conceptualised. If restorative justice is primarily understood as 'the repair of justice through reaffirming a shared value consensus in a bilateral process', it is understandable that 'concerns about shared values are primarily related to restorative justice', while 'concerns about status and power are primarily related to retributive justice' (Wenzel et al., 2008: 375). And if the building of renewed value consensus is seen as the main goal of restorative justice, it is understandable that people will endorse a restorative rather than a punitive, retributive response when they perceive a shared identity (or a shared group membership) with the offender (Gromet \& Darley, 2009: 55).

Similarly, if retributive justice is primarily contrasted with compensatory justice aimed at compensating the victim of the harm done instead of punishing the harm-doer, it is understandable that people prefer retribution in cases of severe crimes, like rape or kidnapping, where it seems difficult to genuinely 'compensate' the victim (Van Prooijen, 2010).

Conceptualisations of restorative justice in terms of reaffirming value consensus or compensating the victim neglect the importance of the symbolic functions that not only retribution but also restorative procedures may have. As we saw, victims experience the discomfort, pain and/or (material) loss caused by a perpetrator in many cases as less important than the symbolic elements that are incorporated into the assault. They are not just physically or materially harmed, they have been wronged (Duff, 2011: 70). They feel disempowered and degraded. That is why they value the symbolic effect of justice procedures in terms of regaining respect and dignity more than possible (material) compensation. This means that if restorative justice aims to be a better and more direct way of serving the needs of victims than retributive justice, we need to conceptualise restorative justice procedures primarily in terms of empowerment, self-respect and 
building interpersonal dignity (Aertsen, Bolívar, De Mesmaecker \& Lauwers 2011). In this way, restorative justice can be regarded as a kind of 'reversed retribution' (Walgrave, 2004/2010: 55-56), because it directs the mechanism of requital ('paying-back') and compensation directly to the victim who has been wronged instead of taking the inefficient detour of degrading and incapacitating the offender, a detour that often amounts to nothing more than adding violence to violence. Restorative justice as empowerment is thus a form of positive recompensation.

\section{Restorative justice as empowerment}

Recall that punitive retribution might (indirectly) serve the victim in three ways: (1) by restoring her as an active actor (autonomy), (2) by restoring the victim's prestige (status), and (3) by giving the victim voice as a defender of important values. Exactly on these issues restorative justice procedures might do much better than retributive justice mechanisms.

\subsection{Back in the driver's seat: restoring autonomy}

One early basis of the restorative justice movement was Nils Christie's (1977) conviction that offences should be considered as issues that belong to victims and offenders and not to criminal justice institutions and their officials.

Victims of violent crime want to play a role and have their voice heard in the judicial proceedings. However, the criminal justice system does not sufficiently meet these concerns. Respondents felt alienated and uninvolved in the judicial procedures that dealt with the drama that befell them. Victimization already left them feeling somewhat disoriented, or even destroyed. The depersonalization of the judicial file and the feeling of being excluded only added to this feeling of alienation (Van Camp, 2014: 102).

Studies into the consequences of victimisation show that victims experience a profound loss of control. They need to recover their autonomy (Herman, 1992/2015: 33 ff). This why it is so important for victims to have process control, the opportunity to be actively involved and have one's concerns expressed and to be heard (Van Camp, 2014: 84).

Restorative justice aims to bring victims back into the driver's seat of the process. Victims participating in restorative procedures appear to feel more in control because they have the chance to make many choices at the start of the intervention (shall I participate?) as well as throughout the whole process, for example, whether to have shuttle or face-to-face communication with the perpetrator (Armstrong, 2012). Restorative procedures are much more suited to restore 
autonomy in the victim than the impersonal juridical processes with which modern states try to effect retribution. ${ }^{6}$

\subsection{Facing the offender: restoring dignity and self-assurance}

Restorative procedures make it possible for victims to address directly the offender, and this is something that may be of great help, even for victims of serious crimes like sexual offences (McGlynn, Westmarland \& Godden, 2012). In victim-offender mediation programmes, victims get the opportunity to vent their emotions in front of the offender, describe the consequences of victimisation and ask for explanations. It appears that victims who participate in such programmes have a much better sense of being heard and acknowledged than in the context of criminal justice procedures where they are often heard only as witness (Wemmers \& Cyr, 2006). Victims feel validated when offenders are able to offer an apology (Choi, Green \& Kapp, 2010), but even when this result does not obtain, they experience their active role and the respectful treatment by the mediator and others involved as distinctively empowering (Harris, Walgrave \& Braithwaite, 2004). In general, for victims, the restorative procedure itself is more important than the outcome. Regardless of whether the process results in favourable outcomes like answers or an apology, most victims experience it as helpful. The possibility to look the offender in the eye and confront them with the consequences of victimisation is empowering in itself (Choi, Bazemore \& Gilbert, 2012).

Also, meeting the individual perpetrator helps the victim not to overgeneralise the event, which will happen if the offender is perceived as belonging to a large, anonymous group of perpetrators who together make the world a dangerous place. Such a perception fosters the negative feeling as if nowhere is safe. Individualising the offender as a person who did a bad thing may, therefore, help building a victim's self-assurance and feeling of control (Pemberton, Winkel \& Groenhuijsen, 2007).

Victims participating in restorative justice practices perceive the procedures as fair and helpful, not because it enables them to make demands or get compensation for possible losses, but because it promotes recognition, self-assurance and understanding (Wemmers \& Cyr, 2006).

\subsection{Interaction and dialogue: restoring meaning}

Restorative procedures facilitate interaction between victim and offender (either directly or via a mediator), so that the victim may get answers and clarification. If

6 What about the autonomy of the perpetrator? In line with Immanuel Kant, one could argue that the retributive view of justice is a way of acknowledging the status of perpetrators as morally responsible, autonomous agents, and thus a way of upholding the dignity of wrongdoers (see Baehler, 2007: 292). Restorative justice does not take such an abstract idea of dignity as viable, though. It understands dignity as resulting from mutual acknowledgement in relationships. As such, restorative practices can contribute to the dignity of not only the victim, but also the perpetrator, whose (life-)story is also heard and whose position as partner in a respectful dialogue is acknowledged. 
a dialogue is realised, this may further enhance the opportunity for victims of reconstructing the truth, which is needed for closure (Armstrong, 2012; Van Camp, 2014: 103; Shapland \& Hall, 2007).

Crime victims need answers to disturbing questions: Why me? What exactly has happened? What was my role? Answers to these questions may be needed to build a coherent narrative and find meaning (Kirkwood, 2010) and to counter feelings of self-blame that impede the experience of self-worth. Also, clarification about what has happened may prevent burdensome processes of rumination (repetitious dwelling on the negative experience) and unwanted afterthoughts (Pemberton et al., 2007).

Restorative justice procedures, which aim to establish a dialogue between victim and perpetrator, are much better suited to reach clarification than the adversarial practices in retributive procedures (like interrogations in court). Note also that entering into a dialogue with the offender is not only a matter of getting the answers for the sake of knowing the answers. Receiving answers ultimately fosters a feeling of acknowledgement that is conducive to dignity (Tyler, 1994).

\subsection{Facing the community: restoring face}

Many victims experience isolation after the crime (Bennet, 2007: 252). They feel disconnected to the world as a safe place (Herman, 1992/2015: 51ff). His or her image of a fair world in which everybody is treated respectfully has been damaged. They are part of a story in which values have been disrupted and which contrasts with the accepted moral order. This may affect their image of themselves and their social relationships. Victims feel helpless and often feel shame for what has happened.

Restorative justice processes are meant to reconnect victims (and offenders!) to the community, not only by giving them positive support but also by helping victims to give voice to the values they expect to share with the offender and with the wider community and to express their indignation about the breach of accepted moral rules (Van Camp, 2014: 130). Victims are allowed into a position in which they themselves stand up for what is commonly regarded as normatively imperative. Not the judicial authorities are the defenders of important values of justice, but those who have been treated unjustly, which may strengthen their sense of standing and self-worth. Victims in restorative practices appear to be willing to engage themselves in order to contribute to a safer society and even help the offender, or offer him forgiveness, as well work on their own healing process (Armour \& Umbreit, 2006). Particularly, the victim's engagement in such a role as social actor, which goes beyond the personal level of their case, seems to be conducive to true empowerment as it strengthens social dignity and selfesteem (Aertsen et al., 2011). 


\section{Conclusion}

Restoration processes may be profoundly empowering if victims can exercise control and be 'agents' instead of 'patients' (Presser \& Hamilton, 2006), if they have the opportunity to face the offender in a safe environment, and if they can say what they want to say, ask questions for further information and enter into a dialogue about values. A restoration process may serve to restore a victim's belief in a just world and to make sense of the victimising event, which is conducive to positive acknowledgement. Victims may acquire autonomy, dignity and standing as active agents in their case and become promoters of reflection and action with regard to more general concerns.

Even so, favouring restorative procedures above retributive punishment, also in case of serious offences, may be seen as amounting to a betrayal of the victims of crime. On the other hand, implementing highly punitive measures could be regarded as a way of taking the side of victims (Fattah, 2007: 212). However, I hope to have made clear that such a view is nothing but self-deception. Retributive punishment is a profoundly inefficient, indirect and even ineffective way of helping the victims of crime. Apart from a temporary and short-lasting satisfaction of vindictive desires, it does not bring the victim what empowering restorative procedures can realise. Restorative justice can do better and can do more, as long as it is understood as a way of empowering victims, restoring their dignity and standing, and equalising the relationship with the offender(s). Restorative justice aims at honouring the offended, not by humiliating the offender, but by restoring healthy relationships.

But does restorative justice also account for the broader, public impact of offences? Not only victims, offenders and their peers are stakeholders of what is going on in crime, but also the public at large. Is punitive retribution not the most appropriate way to react to social unrest and to express blame? I don't think so. Censuring crime is first and foremost a communicative action: we want the offender and the public to understand our strong disapproval of the offence. But 'good communication needs adequate settings' (Walgrave, 2004/2010: 50), and there is every reason to think that offenders will be less open to communication in the antagonistic setting of a courtroom where they are threatened with punishment than in mediation conferences where victim(s), offender(s) and their peers are present. And because the public disapproval will be closely connected to the symbolic import of an offence, addressing exactly this import by aiming to restore the dignity and standing of the victim and defending shared values will meet at least an important part of public expectations. ${ }^{7}$

On all counts, restorative justice appears to be a more direct and effective way of answering offences and countering the wrong done by offenders. If the perpetrator endures the hardship of moral condemnation, loss of standing and

7 One of the important issues for further research in victimology as well as social and moral psychology probably is the way vindictive impulses in public reactions may be influenced by testimonies and reports on how restorative procedures honour and empower victims and their peers. Nuanced analyses like those by Vicky De Mesmaecker (2010) deserve imitation and follow-up. 
particular restorative obligations, such a pain is not the aim of restorative justice. The aim is to restore the dignity of the victim and foster healthy social relations.

We might think back of the story of Mordecai. While his life is in danger, the king honours him. For Haman, this means humiliation, but humiliating Haman was never the purpose of honouring Mordecai, nor was Haman's humiliation the cause of Mordecai's dignity. Haman loses his face in front of the community, which is illustrated in the story as he literarily covers his head, so that he doesn't have to face his peers. Similarly, when Esther is honoured by the king who hears her plea, Haman humiliates himself by throwing himself on her bed. The king is furious and at that point Haman's face is covered by the king's servants as a sign that he is socially dead already. Finally, the Jews are allowed to take up their weapons against those who threaten to kill them. But this is not a case of revenge, but of pure self-defence. There is no message of retaliation in Esther's story. The message is about the dignity the oppressed receive, not by humiliating their oppressors, but by standing up for themselves. ${ }^{8}$

\section{References}

Achilles, M. \& Zehr, H. (2001). Restorative justice for crime victims: the promise and the challenge. In G. Bazemore \& M. Schiff (eds.), Restorative community justice: repairing harm and transforming communities (pp. 87-99). Cincinnati: Anderson Publishing.

Aertsen, I., Bolívar, D., De Mesmaecker, V. \& Lauwers, N. (2011). Restorative justice and the active victim: exploring the concept of empowerment. Temida, Journal of Victimization, Human Rights and Gender, 14, 5-19.

Armour, M.P. \& Umbreit, M.S. (2006). Victim forgiveness in restorative justice dialogue. Victims and Offenders, 1, 123-140.

Armstrong, J. (2012). Factors contributing to victims' satisfaction with restorative justice practice: a qualitative examination. British Journal of Community Justice, 10, 39-54.

Baehler, K. (2007). Justifying restorative justice. In G.M. Maxwell \& J.H. Liu (eds.), Restorative justice and practices in New Zealand: towards a restorative society (pp. 289-299). Wellington: Wipf and Stock Publishers.

Bennett, C. (2007). Satisfying the needs and interests of victims. In G. Johnstone \& D.W. Van Ness (eds.), Handbook of restorative justice (pp. 247-264). Collumpton: Willan Publishing.

Bentham, J. (1962). Principles of penal law. In J. Bowring (ed.), The works of Jeremy Bentham (pp. 365-498). New York: Russel and Russel.

Berlin, A. (2001). The JPS Bible commentary. Esther. Philadelphia: The Jewish Publication Society.

Bies, R.J. \& T.M. Tripp (1996). Beyond distrust: getting even and the need for revenge. In R. Kramer \& T. Tyler (eds.), Trust in organisation (pp. 246-260). Thousand Oaks: Sage Publishing.

Braithwaite, J. (1989). Crime, shame, and reintegration. Cambridge: Cambridge University Press.

8 I would like to thank Prof. Fernando Enns (Amsterdam Center for Religion Peace and Justice Studies), two anonymous reviewers and a member of the editorial team of this Journal for helpful comments. 
Braithwaite, J. (2002). Restorative justice and responsive regulation. New York: Oxford University Press.

Carlsmith, K.M. \& Darley, J.M. (2002). Why do we punish? Deterrence and just deserts as motives for punishment. Journal of Personality and Social Psychology, 83, 284-299.

Carlsmith, K.M., Wilson T.D. \& Gilbert, D.T. (2008). The paradoxical consequences of revenge. Journal of Personality and Social Psychology, 95, 1316-1324.

Choi, J.J., Bazemore, G. \& Gilbert, M.J. (2012). Review of research on victims' experiences in restorative justice: implications for youth justice. Children and Youth Services Review, 34, 35-42.

Choi, J.J., Green, D.L. \& Kapp, S.A. (2010). Victimization, victims' needs, and empowerment in victim offender mediation. International Review of Victimology, 17, 269-290.

Christie, N. (1977). Conflicts as property. British Journal of Criminology, 17, 1-15.

Darley, J.M., Carlsmith, K.M. \& Robinson, P.H. (2000). Incapacitation and just deserts as motives for punishment. Law and Human Behavior, 24, 659-683.

Darley, J.M. \& Pittman, T.S. (2003). The psychology of compensatory and retributive justice. Personality and Social Psychology Review, 7, 324-336.

Darley, J.M. (2010). Citizens' Assignments of Punishments for Moral Transgressions: A Case Study in the Psychology of Punishment. Ohio State Journal of Criminal Law, 8, 101-17.

De Mesmaecker, V. (2010). Building social support for restorative justice through the media: is taking the victim perspective the most appropriate strategy? Contemporary Justice Review, 13, 239-267.

De Quervain, D.J.-F., Fischbacher, U., Treyer, V., Schellhammer, M., Schnyder, U., Buck, A. \& Fehr, E. (2004). The neural basis of altruistic punishment. Science, 305, 1254-1258.

Duff, R.A. (2001a). Restorative punishment and punitive restoration. In L. Walgrave (ed.), Restorative justice and the law (pp. 82-100). Cullompton: Willan Publishing.

Duff, R.A. (2001b). Punishment, communication, and community. New York: Oxford University Press.

Duff, R.A. (2011). Responsibility, restoration, and retribution. In M. Tonry (ed.), Retributivism has a past: has it a future? (pp. 63-81). Oxford: Oxford University Press.

Durlauf, S.N. \& Nagin, D.S. (2011). The deterrent effect of imprisonment. In P.J. Cook, J. Ludwig \& J. McCrary (eds.), Controlling crime: strategies and tradeoffs (pp. 43-94). Chicago: University of Chicago Press.

Elster, J. (1990). Norms of revenge. Ethics, 100, 862-885.

Fattah, E.A. (2007). Is punishment the appropriate response to gross human rights violations? Is a non-punitive justice system feasible? Acta Juridica, 1, 209-227.

Frijda, N.H. (1994). The lex talionis: on vengeance. In S.H.M. van Goozen, N.E. Van de Poll, J.A. Sergeant (eds.), Emotions: essays on emotion theory (pp. 263-289). Hillside: Erlbaum.

Greenwell, J., Dengerink, H.A. (1973). The role of perceived versus actual attack in human physical aggressions. Journal of Personality and Social Psychology, 26, 66-71.

Gromet, D.M. \& Darley, J.M. (2009). Punishment and beyond: achieving justice through the satisfaction of multiple goals. Law \& Society Review, 43, 1-38.

Haidt, J., Sabini, J., Gromet, D. \& Darley, J.M. (2010). What exactly makes revenge sweet? How anger is satisfied in real life and at the movies (manuscript on file with author).

Harris, N., Walgrave L. \& Braithwaite, J. (2004), Emotional dynamics in restorative conferences. Theoretical Criminology, 8, 191-210.

Hart, H.L.A. (1968). Punishment and responsibility. Oxford: Clarendon Press.

Hegel, G.W.F, (1821/1967). Philosophy of right. T.M. Knox (trans.). Oxford: Oxford University Press. 
Herman, J. (1992/2015). Trauma and recovery. New York: Basic Books.

Kant, I. (1996). The metaphysics of morals. In Mary J. Gregor (trans.), Immanuel Kant. Practical philosophy (pp. 353-604). Cambridge: Cambridge University Press.

Kirkwood, S. (2010). Restorative justice cases in Scotland: factors related to participation, the restorative process, agreement rates and forms of reparation. European Journal of Criminology, 7, 107-122.

Kleinig, J. (2011). What dies wrongdoing deserve. In M. Tonry (ed.), Retributivism has a past: has it a future? (pp. 46-58). Oxford: Oxford University Press.

Laniak, T.S. (1998). Shame and honor in the Book of Esther (SBL Dissertation Series 165). Atlanta: Society of Biblical Literature.

Mattinson, J. \& Mirrlees-Black, C. (2000). Attitudes to crime and criminal justice. London: Home Office.

McGlynn, C., Westmarland, N. \& Godden, N. (2012). 'I just wanted him to hear me': sexual violence and the possibilities of restorative justice. Journal of Law and Society, 39, 213-240.

Merry, S.E. \& Silbey, S.S. (1984). What do plaintiffs want? Reexamining the concept of dispute. The Justice System Journal, 9, 151-178.

Miller, D.T. (2001). Disrespect and the experience of injustice. Annual Review of Psychology, 52, 527-553.

Moore, C.A. (1971). The anchor Bible. Esther. Garden City: Doubleday \& Co.

Nozick, R. (1983). Philosophical explanations. Cambridge: Harvard University Press.

Okimoto, T.G. \& Wenzel, M. (2008). The symbolic meaning of transgressions: towards a unifying framework of justice restoration. In K. Hegtvedt \& J. Clay-Warner (eds.), Advances in group processes (pp. 291-326). Bingley: Emerald.

Okimoto, T.G. \& Wenzel, M. (2009). Punishment as restoration of group and offender values following a transgression: value consensus through symbolic labeling and offender reform. European Journal of Social Psychology, 39, 346-367.

Okimoto, T.G., Wenzel, M. \& Feather, N.T. (2012). Retribution and restoration as general orientations towards justice. European Journal of Personality, 26, 255-275

Orth, U. (2003). Punishment goals of crime victims. Law and Human Behavior, 27, 173-186.

Pemberton, A., Winkel F.W. \& Groenhuijsen, M.S. (2007). Taking victims seriously in restorative justice. International Perspectives in Victimology, 3, 4-14.

Presser, L. \& Hamilton, C.A. (2006). The micropolitics of victim-offender mediation. Sociological Inquiry, 16, 316-342.

Radelet, M.L. \& Lacock, T.L. (2009). Do executions lower homicide rates? The views of leading criminologists. Journal of Criminal Law \& Criminology, 99, 489-507.

Shapland, J. \& Hall, M. (2007). What do we know about the effects of crime on victims? International Review of Victimology, 14, 175-217.

Simon, J. (2000). The 'society of captives' in the era of hyper-incarceration. Theoretical Criminology, 4, 285-308.

Singer, T., Seymour, B., O’Doherty, J.P., Stephan, K.E., Dolan, R.J. \& Frith, C.D. (2006). Empathic neural responses are modulated by the perceived fairness of others. Nature, 439, 466-469.

Tedeschi, J.T. \& Nessler, M.S. (1993). Grievances: developments and reactions. In: R.B. Felson \& J.T. Tedeschi (eds.), Aggression and violence: social interactionist perspectives (pp. 13-46). Washington: American Psychological Association.

Tyler, T.R. (1994). Psychological models of the justice motive: antecedents of distributive and procedural justice. Journal of Personality and Social Psychology, 67, 850-863.

Van Camp, T. (2014). Victims of violence and restorative practices. Finding voice. New York: Routledge. 
Van Prooijen, J.-W. (2010), Retributive versus compensatory justice: Observers' preferences for punishing in response to criminal offenses. European Journal of Social Psychology, 40, 72-85.

Van Wely, M. (2013). Levenslang! De straf en de daders. Hilversum: Just Publishers.

Vidmar, N. (2001). Retribution and revenge. In L.J. Sanders \& V.L. Hamilton (eds.), Handbook of justice research in law (pp. 31-63). New York: Kluwer Academic.

Walgrave, L. (2004/2010). Has restorative justice appropriately responded to retribution theory and impulses? In H. Zehr \& B. Toews (eds.), Critical issues in restorative justice (pp. 47-60). London: Lynne Rienner Publishing.

Walker, N. (1995). Nozick's revenge, Philosophy, 70, 581-586.

Weiner, B., Graham, S. \& Reyna, C. (1997). An attributional examination of retributive versus utilitarian philosophies of punishment. Social Justice Research, 10, 431-452.

Wemmers, J.-A. \& Cyr, K. (2006). What fairness means to crime victims: a social psychological perspective on victim-offender mediation. Applied Psychology in Criminal Justice, 2, 102-128.

Wenzel, M. \& Okimoto, T.G. (2010). How acts of forgiveness restore a sense of justice: Addressing status/power and value concerns raised by transgressions. European Journal of Social Psychology, 40, 401-417.

Wenzel, M., Okimoto, T.G., Feather, N.T. \& Platow, M.J. (2008). Retributive and restorative Justice. Law and Human Behaviour, 32, 375-389.

Wenzel, M., Okimoto, T.G., Feather, N.T. \& Platow, M.J. (2010). Justice through consensus: shared identity and the preference for a restorative notion of justice. European Journal of Social Psychology, 40, 909-930.

Zaibert, L. (2006). Punishment and revenge. Law and Philosophy, 25, 81-118.

Zehr, H. (1990/2015). Changing lenses. Restorative justice for our times. Harrisonburg: Herald Press.

Zehr, H. (1998). Justice as restoration, justice as respect. The Justice Professional, 11, 71-87.

Zehr, H. (2014). The little book of restorative justice: revisited and updated. Delaware: Skyhorse Publishing. 